\title{
MODEL IMPLEMENTASI PENDIDIKAN KARAKTER MELALUI PENDEKATAN TERINTEGRASI DALAM PERKULIAHAN PADA JURUSAN PAI-FITK UIN MAULANA MALIK IBRAHIM MALANG
}

\author{
Mujtahid
}

Fakultas Ilmu Tarbiyah dan Keguruan UIN Maulana Malik Ibrahim Malang

Email: mujtahid75@gmail.com

\begin{abstract}
The objective of this research is to meticulously investigate the model of character education implementation by the use of integrated approach during the course at Islamic Education in the Faculty of Tarbiyah and Teacher Training, Maulana Malik Ibrahim State Islamic University of Malang. It focuses on three points encompassing religious, self-personality and social characters that were developed in the learning and teaching process. By purposively selecting the analytical-critical-descriptive approach, the research data were qualitatively obtained by interviews, observations and documentations. The findings reveal three main aspects. The first is a model of religious character that is constructed by thoyyibah texts (basmallah and hamdalah), reciting al Quran, prayers, and dzikr as the manifestation of pious values and beliefs to Allah. The second point is self-personality model as the character construction that is instilled through the familiarization of discipline, sincerity and responsibility during the courses that involve learning process, instructional practice and learning evaluation. The third is the construction of social characters including tolerance, social respects and real democracy in learning system.
\end{abstract}

Penelitian ini bertujuan untuk mengkaji model implementasi pendidikan karakter melalui pendekatan terintegrasi dalam perkuliahan jurusan Pendidikan Agama Islam Fakultas Ilmu Tarbiyah dan Keguruan Universitas Islam Negeri Maulana Malik Ibrahim Malang. Penelitian ini difokuskan pada tiga hal, yaitu karakter religius, karakter kepribadian diri, dan karakter sosial yang dikembangkan melalui proses pembelajaran. Penelitian ini bersifat kualitatif 
dengan pendekatan studi lapangan. Data penelitian digali melalui metode interview, observasi dan dokumentasi. Berdasarkan fokus tersebut, penelitian ini menghadirkan temuan: Pertama, model karakter religius, yaitu karakter yang dikonstruk melalui pembiasaan perkuliahan dengan pembudayaan membaca kalimat thoyyibah (basmalah dan hamdalah), tilawah al Quran, do'a dan dzikir sebagai manisfestasi aktualisasi nilai-nilai keimanan dan keyakinan kepada Allah SWT. Kedua, model karakter kepribadian diri, yakni konstruksi karakter yang ditanamkan melalui pembiasaan disiplin, jujur dan tanggungjawab dalam semua aktivitas perkuliahan yang meliputi aspek proses, pelaksanaan dan evaluasi pembelajaran. Ketiga, konstruksi karakter sosial, yakni karakter yang meliputi toleransi, kepedulian sosial dan demokratis yang nyata dalam sistem pembelajaran.

Keywords: character education, integrated approach, islamic education

\section{Pendahuluan}

Prinsip mendasar tentang pengembangan karakter di Indonesia sejatinya telah dirumuskan pada fungsi dan tujuan pendidikan nasional. Pasal 3 UndangUndang Nomor 20 Tahun 2003 Tentang Sistem Pendidikan Nasional, menyatakan bahwa "Pendidikan nasional berfungsi mengembangkan kemampuan dan membentuk watak serta peradaban bangsa yang bermartabat dalam rangka mencerdaskan kehidupan bangsa, bertujuan untuk berkembangnya potensi peserta didik agar menjadi manusia yang beriman dan bertakwa kepada Tuhan Yang Maha Esa, berakhlak mulia, sehat, berilmu, cakap, kreatif, mandiri, dan menjadi warga negara yang demokratis serta bertanggung jawab”.

Ketentuan undang-undang tersebut dapat dimaknai bahwa pendidikan nasional mendorong terwujudnya generasi penerus bangsa yang memiliki karakter religius, berakhlak mulia, cendekia, mandiri, dan demokratis. Seiring dengan tujuan pendidikan ini pula, pemerintah telah mencanangkan pembangunan karakter bangsa dengan empat nilai inti, yaitu jujur, cerdas, tangguh, dan peduli.

Sejalan dengan peta jalan utama (road map) lembaga pendidikan tinggi Islam di Kementerian Agama bahwa pendidikan karakter merupakan bagian penting yang harus diwujudkan dalam membangun kualitas insan paripurna. Direktorat Pendidikan Tinggi Islam menegaskan agar output perguruan tinggi Islam mampu bersaing dalam kancah global. Seiring dengan itu, Direktorat Diktis merespon dan menjawab tantangan tersebut, dengan menghadirkan nilai-nilai pendidikan Islam sebagai pendorong peradaban dan berbasis kehidupan seluruh umat manusia.

UIN Maulana Malik Ibrahim Malang melalui visinya, mengedepankan 
nilai-nilai keunggulan yang merupakan cerminan dari insan yang berkarakter, khususnya karakter Ulul Albab. Pendidikan yang ingin dihasilkan UIN Maulana Malik Ibrahim Malang yaitu melahirkan ulama' yang intelektual profesional dan atau intelek profesional yang ulama'. Tujuan ini sangat sarat dengan nilai-nilai karakter yang akan diwujudkan dalam proses pembelajaran di masing-masing jurusan, termasuk Jurusan Pendidikan Agama Islam.

Karakter Ulul Albab yang ditanamkan kepada mahasiswa UIN Maulana Ibrahim Malang tercermin dalam enam belas hal yaitu: (1) Memiliki akal pikiran yang jernih dan murni yang mampu menyelesaikan masalah dengan adil, yang benar dikatakan benar dan yang salah dikatakan salah; (2) Mampu hidup dalam suasana kebhinekaan (pluralisme/ multikulturalisme) dan berusaha menghindari interaksi yang dapat menimbulkan disharmoni, kesalafahaman, dan keretakan hubungan; (3) mampu menangkap pelajaran (hikmah), memilih dan memilah antara jalan yang benar (haq) dan buruk (bathil); (4) Giat melakukan kajian dan penelitian sesuai dengan bidangnya dan berusaha menghindari fitnah dan malapetaka dari proses dan hasil kajian atau penelitiannya; (5) Mementingkan kualitas hidup disamping kuantitasnya, baik dalam keyakinan, ucapan maupun perbuatan); (6) Sadar akan kehadiran Tuhan dalam segala situasi dan kondisi, baik saat bekerja maupun beristirahat, dan berusaha mengenali Allah SWT dengan qalbu (dzikir), serta mengenali alam semesta dengan akal (pikir), sehingga sampai pada bukti yang sangat nyata tentang keesaan dan kekuasaan Allah SWT; (7) Fokus (concern) terhadap kesinambungan pemikiran dan sejarah, sehingga tidak mau melakukan loncatan sejarah; (8) Memiliki ketajaman hati dalam menangkap fenomena yang dihadapinya; (9) Mampu dan bersedia mengingatkan orang lain berdasar ajaran dan nilai-nilai Ilahi dengan cara yang lebih komunikatif; (10) Merenungkan dan mengkaji ayat-ayat Tuhan baik yang tanziliyah (wahyu) maupun kauniyah (alam semesta), dan berusaha menangkap pelajaran darinya; (11) Sabar dan tahan uji walaupun ditimpa musibah dan diganggu oleh setan (jin dan manusia); (12) Mampu membedakan mana yang lebih bermanfaat dan menguntungkan dan mana pula yang kurang bermanfaat dan menguntungkan bagi kehidupannya di dunia dan akhirat kelak; (13) Bersikap terbuka terhadap pendapat, ide atau teori dari manapun datangnya, dan selalu menyiapkan grand-concept/ theory, atau kriteria yang jelas yang dibangun dari petunjuk wahyu, kemudian menjadikanya sebagai piranti dalam mengkritisi pendapat, ide atau teori tersebut, untuk selanjutnya berusaha dengan sungguh-sungguh dalam mengikuti pendapat, ide atau teori yang terbaik; (14) Orang yang sadar 
dan peduli terhadap pelestarian lingkungan hidup; (15) Berusaha mencari petunjuk dan pelajaran dari fenomena historik atau kisah-kisah terdahulu; (16) Menghindari perbuatan onar, keresahan dan kerusuhan, serta berbuat makar di masyarakat.

Berdasarkan reasoning di atas, maka fokus penelitian ini diarahkan untuk mengkaji tentang bagaimana desain implementasi model pendidikan karakter melalui pendekatan terintegrasi dalam perkuliahan Jurusan Pendidikan Agama Islam Fakultas Ilmu Tarbiyah dan Keguruan UIN Maulana Malik Ibrahim Malang, pada aspek karakter religius, karakter kepribadian diri dan karakter sosial.

\section{Konsep Pendidikan Karakter}

Istilah karakter, dalam kajian Pusat Bahasa Depdiknas diartikan sebagai "bawaan, hati, jiwa, kepribadian, budi pekerti, perilaku, personalitas, sifat, tabiat, temperamen, watak". Sedangkan berkarakter dimaknai "berkepribadian, berperilaku, bersifat, bertabiat, dan berwatak" (Syahroni, 2015: 1). Menurut Tadkiroatun Musfiroh, seperti yang dikutip Syahroni, bahwa karakter mengacu kepada serangkaian sikap (attitudes), perilaku (behaviors), motivasi (motivations), dan keterampilan (skills). Dalam bahasa Yunani, karakter berarti "to mark" atau menandai dan memfokuskan bagaimana mengaplikasikan nilai kebaikan dalam bentuk tindakan atau tingkah laku. Karakter merupakan kaidah-kaidah yang menjadi ukuran baik dan buruk terhadap suatu sikap, ucapan, dan tindakan.

Menurut Thomas Lickona, seperti yang kutip oleh Masnur Muslich bahwa karakter merupakan sifat alami seseorang dalam merespon situasi secara bermoral, yang dimanifestasikan dalam tindakan nyata melalui tingkah laku yang baik, jujur, bertanggungjawab, menghormati orang lain dan karakter mulia lainnya (Muslich, 2011: 36-39). Terkait dengan maksud karakter tersebut, terdapat enam pilar utama yang menjadi acuan, yaitu: (a) Trustworthiness, bentuk karakter yang membuat seseorang menjadi berintegritas, jujur dan loyal; (b) Fairless, bentuk karakter yang membuat seseorang memiliki pemikiran terbuka serta tidak suka memanfaatkan orang lain; (c) Caring, bentuk karakter yang membuat seseorang memiliki sikap peduli dan perhatian; (d) Respect, bentuk karakter yang membuat seseorang selalu menghargai dan menghormati orang lain; (e) Citizenship, bentuk karakter yang membuat seseorang sadar hukum dan peraturan serta peduli terhadap lingkungan alam; (f) Responsibility, bentuk karakter yang membuat seseorang bertanggungjawab, disiplin, dan selalu 
melakukan sesuatu dengan sebaik mungkin.

\section{Prinsip Implementasi Pendidikan Karakter}

Dalam kerangka acuan pendidikan karakter yang dikeluarkan oleh Direktorat Ketenagaan Direktorat Jenderal Pendidikan Tinggi Kementerian Pendidikan Nasional tahun 2010, dijelaskan bahwa secara prinsipil, pengembangan karakter tidak dimasukkan sebagai pokok bahasan tetapi terintegrasi kedalam mata pelajaran, pengembangan diri dan budaya satuan pendidikan. Oleh karena itu pendidik dan satuan pendidikan perlu mengintegrasikan nilai-nilai yang dikembangkan dalam pendidikan karakter ke dalam kurikulum, silabus yang sudah ada.

Prinsip pembelajaran yang digunakan dalam pengembangan pendidikan karakter mengusahakan agar peserta didik mengenal dan menerima nilai-nilai karakter sebagai milik peserta didik dan bertanggung jawab atas keputusan yang diambilnya melalui tahapan mengenal pilihan, menilai pilihan, menentukan pendirian, dan selanjutnya menjadikan suatu nilai sesuai dengan keyakinan diri. Dengan prinsip ini peserta didik belajar melalui proses berpikir, bersikap, dan berbuat. Ketiga proses ini dimaksudkan untuk mengembangkan kemampuan peserta didik dalam melakukan kegiatan sosial dan mendorong peserta didik untuk melihat diri sendiri sebagai makhluk sosial (Kemendiknas, 2010: 11). Prinsip implementasi pendidikan karakter dapat dijelaskan sebagai berikut:

1. Berkelanjutan mengandung makna bahwa proses pengembangan nilainilai karakter merupakan sebuah proses panjang dimulai dari awal peserta didik masuk sampai selesai dari suatu satuan pendidikan;

2. Melalui semua mata pelajaran, pengembangan diri, dan budaya satuan pendidikan mensyaratkan bahwa proses pengembangan karakter dilakukan melalui setiap mata pelajaran, dan dalam setiap kegiatan kurikuler, ekstra kurikuler dan kokurikuler. Pengembangan nilai-nilai tersebut melalui keempat jalur pengembangan karakter melalui berbagai mata pelajaran yang telah ditetapkan dalam standar Isi;

3. Nilai tidak diajarkan tapi dikembangkan melalui proses belajar (value is neither cought nor taught, it is learned) mengandung makna bahwa materi nilai-nilai karakter bukanlah bahan ajar biasa. Tidak semata-mata dapat ditangkap sendiri atau diajarkan, tetapi lebih jauh diinternalisasi melalui proses belajar. Artinya, nilai-nilai tersebut tidak dijadikan pokok bahasan yang dikemukakan seperti halnya ketika mengajarkan suatu konsep, teori, prosedur, atau pun fakta seperti dalam mata kuliah atau pelajaran 
agama, bahasa Indonesia, sejarah, matematika, pendidikan jasmani dan kesehatan, seni, ketrampilan, dan sebagainya. Materi pelajaran biasa digunakan sebagai bahan atau media untuk mengembangkan nilai-nilai karakter peserta didik. Oleh karena itu pendidik tidak perlu mengubah pokok bahasan yang sudah ada tetapi menggunakan materi pokok bahasan itu untuk mengembangkan nilai-nilai karakter. Juga, pendidik tidak harus mengembangkan proses belajar khusus untuk mengembangkan nilai. Suatu hal yang selalu harus diingat bahwa satu aktivitas belajar dapat digunakan untuk mengembangkan kemampuan dalam ranah kognitif, afektif, konatif, dan psikomotor. Konsekuensi dari prinsip ini nilai-nilai karakter tidak ditanyakan dalam ulangan ataupun ujian. Walaupun demikian, peserta didik perlu mengetahui pengertian dari suatu nilai yang sedang mereka tumbuhkan pada diri peserta didik. Peserta didik tidak boleh berada dalam posisi tidak tahu dan tidak paham makna nilai terebut;

4. Proses pendidikan dilakukan peserta didik secara aktif dan menyenangkan. Prinsip ini menyatakan bahwa proses pendidikan karakter dilakukan oleh peserta didik bukan oleh pendidik. Pendidik menerapkan prinsip "tut wuri handayani" dalam setiap perilaku yang ditunjukkan peserta didik. Prinsip ini juga menyatakan bahwa proses pendidikan dilakukan dalam suasana belajar yang menimbulkan rasa senang dan tidak indoktrinatif. Diawali dengan perkenalan terhadap pengertian nilai yang dikembangkan maka pendidik menuntun peserta didik agar secara aktif (tanpa mengatakan kepada peserta didik bahwa mereka harus aktif tapi pendidik merencanakan kegiatan belajar yang menyebabkan peserta didik aktif merumuskan pertanyaan, mencari sumber informasi dan mengumpulkan informasi dari sumber, mengolah informasi yang sudah dimiliki, merekonstruksi data/fakta/nilai, menyajikan hasil rekonstruksi/proses pengembangan nilai) menumbuhkan nilai-nilai karakter pada diri peserta didik melalui berbagai kegiatan belajar yang terjadi di kelas, satuan pendidikan, dan tugas-tugas di luar satuan pendidikan (Kemendiknas, 2010: 11-13).

Untuk melaksanakan pengembangan pendidikan karakter memerlukan tiga tahap, yaitu perencanaan, pelaksanaan dan evaluasi hasil. Pada tahap pertama (perencanaan), merumuskan perangkat karakter yang digali, dikristalisasikan dari berbagi sumber, misalnya (1) filosofi agama, Pancasila, UUD 1945, dan UU No. 20 Tahun 2003 beserta ketentuan perundang-undangan turunannya. Tahap kedua (pelaksanaan), menyertakan landasan teoritis mengenai otak (brain theories), psikologis (cognitive development theories, learning theories, theories 
of personality), pendidikan (theories of intruction, educational management theories, curriculum theories) nilai dan moral (axiology, moral culture). Tahap ketiga (hasil evaluasi), memerlukan pertimbangan empiris berupa pengalaman dan praktik terbaik (best practices) dari antara lain tokoh-tokoh, satuan pendidikan unggulan, pesantren, kelompok kultural dan lain-lain (Majid, 2012: 39).

Pengembangan karakter harus terintegrasi dalam kegiatan keseharian baik itu melalui kegiatan belajar mengajar (KBM) di kelas, pembiasaan dalam kegiatan keseharian di lingkungan pendidikan, kegiatan penunjang kurikulum (ektrakurikuler), maupun penerapan pembiasaan dalam kehidupan keseharian di rumah yang sama dengan di satuan pendidikan.

\section{Nilai-nilai Pendidikan Karakter}

Nilai-nilai pendidikan karakter yang dikembangkan melalui satuan pendidikan yaitu mencakup 18 nilai. Pelaksanaan pendidikan karakter pada satuan pendidikan telah teridentifikasi 18 nilai yang bersumber dari agama, Pancasila, budaya, dan tujuan pendidikan nasional, yaitu: (1) Religius; (2) Jujur; (3) Toleransi; (4) Disiplin; (5) Kerja keras; (6) Kreatif; (7) Mandiri; (8) Demokratis; (9) Rasa Ingin Tahu; (10) Semangat Kebangsaan; (11) Cinta Tanah Air; (12) Menghargai Prestasi; (13) Bersahabat/Komunikatif; (14) Cinta Damai; (15) Gemar Membaca; (16) Peduli Lingkungan; (17) Peduli Sosial; (18) Tanggung Jawab (Kemendiknas, 2009: 9-10).

Selain 18 nilai tersebut, lembaga pendidikan dapat menentukan prioritas pengembangannya untuk melanjutkan nilai-nilai lainnya. Nilai-nilai tersebut berdasarkan kondisi lembaga pendidikan masing-masing, yang dilakukan melalui analisis konteks, sehingga dalam implementasinya dimungkinkan terdapat perbedaan jenis nilai karakter yang dikembangkan antara satu lembaga pendidikan dengan lembaga pendidikan lainnya. Implementasi nilai-nilai karakter yang akan dikembangkan dapat dimulai dari nilai-nilai yang esensial, sederhana, dan mudah dilaksanakan, seperti: bersih, rapi, nyaman, disiplin, sopan dan santun, serta masih banyak nilai-nilai lainnya.

Menurut Hetitage Foundation, seperti yang dikutip Mulyasa, bahwa hakikat pendidikan karakter mencakup 9 utama, yakni: (1) cinta kepada Tuhan dan kebenaran; (2) tanggungjawab, disiplin dan mandiri; (3) jujur; (4) hormat dan santun; (5) kasih sayang, peduli dan kerjasama; (6) percaya diri, kreatif, kerja keras dan pantang menyerah; (7) keadilan dan kepemimpinan; (8) baik dan rendah hati, serta; (9) toleransi, cinta damai dan persatuan (Mulyasa, 2011: 15-16).

Nilai-nilai karakter merupakan watak, tabiat serta sifat yang melekat 
pada diri seseorang. Karakter mempengaruhi segenap pikiran, perasaan dan tindakannya. Perwujudan nilai-nilai karakter mulia di atas, seperti yang diungkap Syahroni, berarti setiap individu memiliki pengetahuan tentang potensi dirinya, yang ditandai dengan nilai-nilai seperti reflektif, percaya diri, rasional, logis, kritis, analitis, kreatif dan inovatif, mandiri, hidup sehat, bertanggung jawab, cinta ilmu, sabar, berhati-hati, rela berkorban, pemberani, dapat dipercaya, jujur, menepati janji, adil, rendah hati, malu berbuat salah, pemaaf, berhati lembut, setia, bekerja keras, tekun, ulet/gigih, teliti, berinisiatif, berpikir positif, disiplin, antisipatif, inisiatif, visioner, bersahaja, bersemangat, dinamis, hemat/efisien, menghargai waktu, pengabdian/dedikatif, pengendalian diri, produktif, ramah, cinta keindahan (estetis), sportif, tabah, terbuka, tertib. Individu juga memiliki kesadaran untuk berbuat yang terbaik atau unggul, dan individu juga mampu bertindak sesuai potensi dan kesadarannya tersebut (Syahroni, 2015)

\section{Metode}

Penelitian ini didesain menggunakan jenis penelitian kualitatif dengan pendekatan deskriptif analitis kritis. Metode deskriptif analitis kritis yang digunakan dalam penelitian ini bersifat categorical analyze, yaitu suatu jenis kajian yang digunakan untuk menemukan suatu model tertentu. Metode ini digunakan untuk menemukan corak atau kekhasan desain model implementasi pendidikan karakter yang dikembangkan prodi Pendidikan Agama Islam Fakultas Ilmu Tarbiyah dan Keguruan UIN Maulana Ibrahim Malang yang terintegrasi dalam perkuliahan.

Untuk memperoleh keabsahan data, peneliti melakukan analisis sebagai berikut: Pertama, menguji triangulasi. Peneliti melakukan pemeriksaaan keabsahan data dengan memanfaatkan sesuatu yang lain, membandingkan hasil dokumen, pengamatan, dan wawancara terhadap informan yang telah dipilih secara kredibel. Analisis triangulasi dimaksud untuk menjernihkan apa yang dimaksud atau dicita-citakan oleh pelakunya. Kedua, melakukan diskusi. Untuk menambah keabsahan data yang diperoleh, maka dibutuhkan sebuah diskusi dengan pihak-pihak yang kompeten, terutama dosen dan stakeholders yang terlibat dalam pengembangan kurikulum PAI dan yang memiliki pengetahuan dan keahlian yang memadahi tentang pokok persoalan yang diangkat menjadi penelitian ini. Ketiga, pengecekan ulang. Untuk menjaga keotentikan data yang berasal dari lapangan penelitian, peneliti melakukan pemeriksaan kembali terhadap data yang diperoleh peneliti selama penelitian. 
Data yang tidak ada kaitannya dengan fokus penelitian maka tidak perlu masuk ke dalam pembahasan, sebab hanya dibatasi tentang model implementasi pendidikan karakter pendekatan terintegrasi melalui perkuliahan. Keempat, pencermatan dan penafsiran terhadap data yang begitu beragam secara terusmenerus sampai diperoleh sebuah kesimpulan akhir yang fokus dengan tujuan peneltian yakni model implementasi pendidikan karakter terintegrasi dengan perkuliahan pada jurusan PAI.

Jurusan PAI memiliki visi yaitu "Pada Tahun 2030 menjadi Jurusan/ Program Studi terkemuka dalam menyiapkan tenaga pendidik Agama Islam dan pengelola pada satuan pendidikan keagamaan Islam yang berkarakter Ulul Albab dan memiliki wawasan internasional.” Adapun untuk mencapai visi tersebut, jurusan menetapkan misi antara lain: (a) Menyelenggarakan pendidikan unggul yang dirancang untuk menghasilkan lulusan yang siap menjadi pendidik agama Islam di sekolah/madrasah dan jenis pendidikan keagamaan Islam lainnya, serta menjadi pengelola satuan pendidikan keagamaan Islam; (b) Mempersiapkan lulusan yang berkualitas yang memiliki kekokohan akidah dan kedalaman spiritual, keluhuran akhlak, keluasan ilmu dan kematangan profesional dalam menjalankan tugasnya sebagai tenaga kependidikan Islam; (c) Mengembangkan paradigma baru manajemen pendidikan dan menciptakan iklim akademis religius dalam pengelolaan pendidikan dan pengembangan kompetensi sebagai pendidik agama Islam; (d) Mengembangkan penelitian yang dapat melahirkan dan mengembangkan teori-teori pendidikan Islam baik pada jalur pendidikan formal, non formal maupun informal; (e) Mengembangkan pengabdian kepada masyarakat yang lebih bersifat proaktif dan antisipatif dalam menghadapi dan memecahkan permasalahan pendidikan Islam yang tumbuh dan berkembang di masyarakat; (f) Mengembangkan jaringan kerjasama/kemitraan dengan perguruan tinggi di dalam dan luar negeri, masyarakat pengguna lulusan, dan stakeholders lainnya. Mengembangkan dan menjaga nilai, etika profesional dan moral akademis untuk pengendalian mutu program studi.

\section{Hasil Penelitian}

Model implementasi pendidikan karakter melalui perkuliahan Jurusan PAI yang integral meliputi hal berikut:

a. Karakter Religius

Dalam setiap kegiatan perkuliahan, para dosen Prodi PAI mengajak 
mahasiswa memulai kuliah dengan membaca surat al Fatihah atau sekurangkurangnya dengan membaca basmalah, lalu diteruskan dengan membaca ayat suci al Quran. Hal ini dapat dilihat dalam dokumen kontrak perkuliahan yang setiap dosen dan masing-masing kelas memengang dokumen tersebut. Pada setiap ruang kelas terdapat almari yang berisikan al Quran sejumlah mahasiswa. Inisiasi tersebut merupakan bagian dari upaya untuk mendukung tradisi tilawah al Quran.

Pada pelaksanaannya, kegiatan perkuliahan dosen mengajak para mahasiswa untuk membiasakan melafalkan kata basmalah untuk membuka perkuliahan dan membaca hamdalah untuk menutup kuliah. Makna yang diharapkan dari menanam kebiasaan membaca kalimat tersebut yaitu bahwa setiap memulai dan mengakhiri kegiatan harus memiliki dimensi vertikal, bahwa setiap individu (mahasiswa) harus membangun kesadaran dengan Sang Pencipta. Seperti yang dituturkan oleh Aji Bagus Kelas V/C (1311139) "agar lebih mantap dan barakah dalam belajar, para dosen sering mengajak kami untuk memulai dengan membaca basmalah sebelum perkuliahan dan membaca hamdalah saat menutup perkuliahan. Juga membaca ayat-ayat al Quran, manakala masuk pada jam-jam pertama" (Aji, wawancara: 8 April 2016).

Dua kalimat itu sangatlah pendek dan mudah diucapkan, akan tetapi dampaknya sangat luar biasa bagi pembentukan sikap batin, dan kemantapan pikir para mahasiswa. Segala perbuatan memang harus dimulai dengan sandaran kepada Allah SWT, Dzat yang Maha Kuasa Segalanya. Makna spiritualnya yaitu segala tugas mulia merupakan bentuk Ibadah kepada Allah SWT, termasuk memulai belajar di kelas. Hal ini seperti yang dikatakan Dosen Muda (M. Amin Nur), "Segala perbuatan baik itu ya harus dimulai dengan niat yang baik, seperti membaca basmalah atau jika mau lengkap ya membaca al Fatihah, dan selepas pekerjaan selesai maka membaca hamdalah sebagai tanda rasa syukur kepada Allah SWT" (Amin, wawancara: 8 April 2016).

Bahkan beberapa dosen senior juga mewajibkan membaca al Quran sebelum memulai perkuliahan. Mewajibkan para mahasiswa membaca al Quran sebagai bentuk tanggungjawab dalam mengejawantahkan nilai-nilai peran strategis institusi pendidikan Islam kepada mahasiswa. Lebih khusus lagi berkaitan dengan tujuan mereka kuliah di jurusan Pendidikan Agama Islam. Seperti yang peneliti jumpai, bahwa tampak dalam perkuliahan Suaib Muhammad bahwa masing-masing mahasiswa diajak membaca ayat al Quran, bahkan mereka diuji satu-persatu. Setelah itu, para mahasiswa PAI diajak untuk mengalisis arti mulai dari kata demi kata sampai kalimat yang sempurna. 
Perenungan atas bacaan ayat al Quran tersebut lalu diaktualisasikan dalam sikap, perilaku dan tindakan keseharian mereka (Suaib, wawancara: 9 April 2016).

b. Karakter Kepribadian (Disiplin, tanggung jawab dan jujur)

Dalam membentuk karakter mahasiswa, kegiatan perkuliahan juga mengajak untuk disiplin, baik untuk para dosen maupun sesama mahasiswa. Disiplin merupakan karakter diri yang amat penting dalam mewujudkan komitmen antar orang. Implementasi karakter melalui pembiasaan disiplin juga tidak luput dari kegiatan perkuliahan di kelas.

Untuk membiasakan sikap disiplin, prodi Pendidikan Agama Islam membuat dokumen kontrak perkuliahan yang isinya tentang "keterlambatan dosen dan mahasiswa dalam kelas" yang disepakati bersama. Dokumen ini dijadikan pedoman bagi dosen dan mahasiswa dalam kegiatan perkuliahan. Sekalipun kelihatan transaksional, tetapi masing-masing pihak memperoleh kepastian dalam memulai perkuliahan dengan tepat waktu (disiplin).

Karakter disiplin juga dihubungkan dengan tugas-tugas perkuliahan yang dikerjakan mahasiswa. Setiap tugas yang diberikan dosen kepada mahasiswa juga harus disiplin waktu pengumpulannya. Maknanya yaitu budaya disiplin menjadikan seseorang harus mengelola waktu sebaik mungkin dan seoptimal mungkin.

Seperti yang dikatakan Dosen Pancasila dan Kewarganegaraan, Muh. Hambali "Mahasiswa yang terlambat saya beri hukuman untuk menghafal beberapa surat/ayat al Quran, kadang juga menyanyi sebagai pembelajaran agar mereka disiplin, serta bagi lainnya agar tidak melakukan hal yang sama"(Hambali, wawancara: 8 April 2016).

Sepintas kelihatan upaya yang dilakukan dosen tersebut terkesan berat, akan tetapi sebagai wujud pembudayaan karakter yang tinggi perlu adanya hal-hal demikian. Sehingga muncul kesadaran akan pentingnya menghargai waktu, kesempatan dan kesepakatan yang telah dibangun bersama. Seperti halnya penciptaan budaya religius, budaya disiplin yang termaktub dalam kontrak perkuliahan yang dijadikan sebagai tatanan nilai yang dihargai dan dipedomani bersama.

Budaya disiplin harus menjadi kesadaran bersama (dosen dan mahasiswa) agar menghasilkan budaya akademis yang berkualitas, khususnya dalam meningkatkan kualitas pembelajaran. Budaya disiplin juga ditunjukkan melalui ujian tengah semester maupun ujian akhir semester (UTS/UAS). Mahasiswa yang mengikuti ujian harus hadir tepat waktu sesuai jam ujian mata kuliah. 
Jika mahasiswa datang terlambat, maka mahasiswa harus meminta selembar surat keterangan supaya bisa masuk, bila masih memungkinkan diperkenankan masuk. Begitu juga halnya dengan tugas perkuliahan, mereka juga harus mengumpulkan tepat waktu, jika terlambat maka mereka tidak dilayani, dan nilai tugas tidak diproses oleh dosen.

Selain penuturan Hambali juga disampaikan Sudiyono bahwa mahasiswa yang teledor, tidak hadir mengikuti UTS tanpa alasan yang jelas, maka mahasiwa tersebut tidak diperkenankan ikut ujian susulan, sehingga dipastikan mahasiwa itu tidak lulus. Otoritas dosen memang sangat besar dalam menegakkan disiplin mahasiswa. Walau terkadang mahasiswa tersebut mengantongi surat pengantar dari Jurusan PAI, tetap saja mahasiswa tidak mendapatkan kesempatan mengikuti ujian. Model seperti ini merupakan bagian dari pentingnya menegakkan sikap disiplin bagi mahasiswa.

Hal serupa juga berlaku bagi dosen, misalnya bila dosen terlambat mengumpulkan soal ujian, maka dosen tersebut harus menggandakan soal sesuai dengan jumlah kelas dan mahasiswa, serta harus menyerahkan soal ke ruang ujian, atau panitia ujian. Begitu juga terlambat datang ke kelas sesuai dengan kesepakatan bersama, maka dosen tersebut akan ditinggal oleh mahasiswanya.

Cara-cara tersebut di atas merupakan langkah untuk menanamkan karakter disiplin, baik bagi dosen maupun mahasiswa. Budaya disiplin perlu diterapkan supaya sistem akademik tidak lembek, terganggu dan sebaliknya budaya akademik harus terencana dan berbudaya tinggi.

Untuk menamkan sikap tanggung jawab dan jujur juga tidak luput dari masing-masing dosen melalui perkuliahan. Dalam kegiatan perkuliahan, mahasiwa pasti memeroleh tugas-tugas pokok kuliah yang harus dikerjakan, baik secara individu maupun kelompok. Untuk tugas individu, mahasiswa wajib mengerjakan sendiri dan bebas dari unsur penjiplakan serta harus memenuhi beberapa syarat yang diberikan oleh dosen. Bagi mereka yang tidak memenuhi syarat tersebut, maka tugas mereka tidak akan dinilai, atau dikembalikan untuk direvisi ulang, atau hukuman paling berat yaitu didiskualifikasi dan dinyatakan tidak lulus.

Untuk menanamkan hal tersebut, seperti yang disampaikan Muh. Hambali "Jika saya mendapati tugas yang tidak sesuai dengan instruksi yang saya buat, maka tugas itu akan saya coret, dan harus diganti atau diperbaiki lagi, misalnya sumber rujukan harus minimal 10 buku dan seterusnya". Sebagai dosen yang dianggap paling "streng" dalam perkuliahan terhadap mahasiswa seperti itu justru 
memiliki dampak positif. Mahasiswa harus dapat mempertanggungjawabkan apa yang ditulisnya, juga jujur dalam pengambilan sumbernya. Untuk sistem perkuliahan di Perguruan Tinggi, sikap tanggungjawab dan kejujuran harus dibiasakan dan dipupuk, supaya kelak ketika memasuki dunia kerja mereka terbiasa dengan sifat demikian. Budaya potong kompas, copy paste, mengklaim karya orang harus dijauhkan dari budaya mahasiswa.

Begitu pentingnya sikap tanggungjawab dan jujur dalam kegiatan perkuliahan, para dosen menggunakan strategi masing-masing. Ada sebagian dosen yang mewajibkan karya mahasiswa harus dipublikasikan di website, atau dipresentasikan dan diuji kevalidannya. Mereka yang tidak jujur waktu mengerjakan tugas tersebut akan kelihatan, ketika mempresentasikan atau ditanya soal konten/isinya. Sebagian dosen mewajibkan hal tersebut kepada mahasiswa dengan cara mengirim via e-mail dan cetak, untuk memastikan pekerjaan mahasiswa benar-benar bisa diukur dari segi kejujurannya.

c. Karakter Sosial (Toleransi, Peduli Sosial dan Demokratis)

Dalam kegiatan perkuliahan juga diajarkan tentang pentingnya toleransi (menghargai sesama). Pendekatan perkuliahan biasanya lebih mengedepankan sistem pembelajaran andragogi (pendidikan orang dewasa). Dalam perkuliahan mahasiswa dilatih menghargai sesama, baik secara individu atau kelompok melalui presentasi-presentasi makalah atau kegiatan lainnya. Di jurusan PAI, mahasiswa cenderung homogen dari sisi agama (keyakinan), sementara sisi gender dan latar belakang sosial ekonomi berbeda-beda. Rata-rata mahasiswa per kelas, 60 persen putri dan 40 persen putra.

Pada aktivitas perkuliahan, mahasiswa tampak saling toleransi dalam menghargai pendapat, seperti saat diskusi makalah. Sekalipun terjadi perbedaan pendapat, tetapi disampaikan dengan argumen-argumen yang santun dan fakta-fakta yang logis empiris. Jarang sekali terjadi perdebatan yang menjurus sampai terbawa emosi dan ketegangan, melainkan tampil dalam suasana kewajaran.

Kepedulian sosial dalam kegiatan perkuliahan juga diwujudkan dengan cara-cara seperti belajar bersama (kerjasama), satu sama lain saling membantu. Mahasiswa yang memiliki laptop misalnya, alat itu digunakan bersama untuk presentasi, dan mengakses beberapa informasi yang dibutuhkan oleh timnya. Hal itu seperti terlihat pada kelas V/C, salah seorang rela laptopnya digunakan sebagai sarana untuk presentasi kelompoknya bahkan tak jarang juga untuk kelompok lain, selain untuk bersama-sama sekelompok kerjanya itu. Tidak egois dan juga tidak pelit, yang punya kelebihan membantu mereka yang 
dalam keterbatasan.

Kepedulian sosial juga terwujud melalui iuran kelas, yang dihimpun dan diperuntukkan untuk kegiatan bersama pada kelas itu. Hal itu tampak pada kelas VII (A, B, C, D) yang menyelenggarakan praktik kewirausahaan, dengan menyewa terop, meja dan kursi dengan mengandalkan kebersamaan dan kepedulian. Mereka sukses dan mampu menginspirasi mahasiswa lainnya untuk menggalang kegiatan-kegiatan serupa.

Hal lain yang ditumbuhkan melalui perkuliahan pada Jurusan PAI yaitu sikap demokratis. Baik dosen maupun mahasiswa sama-sama menanamkan jiwa demokratis yang menjadi sarana penting dalam sistem perkuliahan. Dosen mengajar dengan menerapkan aturan-aturan atau pedoman yang sudah ada, kecuali beberapa hal teknis yang belum tertuang dalam aturan. Mahasiswa juga sama, misalnya ketika memilih ketua kelas mereka bermusyawarah atas dasar kemufakatan secara demokratis. Pembelajaran demokrasi tampak nyata di kalangan mahasiswa. Mereka sangat kompak dan bersatu dalam kelas mereka. Perangkat-perangkat kelas dihidupkan dan diaktifkan, untuk mewujudkan kenyamanan belajar.

\section{Pembahasan}

Berdasarkan hasil temuan di atas, maka pada bagian ini peneliti perlu membahas secara kritis dan mendalam. Bagian pertama, mengenai implementasi model karakter religius. Sudah menjadi tradisi pada jurusan PAI, bahwa nilainilai karakter religius merupakan hal pokok yang harus diimplementasikan secara masif. Perkuliahan diawali dengan membaca Basmalah atau surat al Fatihah hal ini merupakan starting point yang mengantarkan kesuksesan hidup seseorang. Dengan membaca basmalah, para dosen dan mahasiswa meyakini dan berharap bahwa pekerjaan atau perbuatan akan berhasil dengan baik karena mendapat bimbingan Allah SWT, memperoleh berkah serta ridha dariNya (Aziz, 2008: 12). Lebih dari itu, setiap muslim wajib meyakini Allah SWT dan Rasulullah Muhammad SAW telah memerintahkan agar untuk memulai setiap pekerjaan dengan mengucap basmalah. Allah sendiri memulai kitabNya (al Quran) hampir semua surah dengan basmalah. Kata ini pula yang diajarkan kepada Nabi Muhammad SAW pertama kali, yakni iqra' bismi rabbika, bacalah dengan nama Tuhanmu.

Perkuliahan sebagai bagian aktivitas mulia, maka membaca basmalah adalah meniatkan diri atas ridha Allah. Kata itu juga bisa bermakna ada unsur ketaatan dan kesadaraan seseorang kepada Allah, atas kegiatan atau aktivitas 
yang dilaksanakannya. Dalam sebuah Hadits dikatakan bahwa, manakala aktivitas tidak didahului dengan membaca basmalah, maka hasilnya tidaklah sah di hadapan Allah SWT. Pada setiap perbuatan, khususnya hal-hal yang berurusan dengan masalah ibadah, wajib hukumnya membaca basmalah, termasuk menuntut ilmu (belajar). Mengapa begitu penting memulai pekerjaan dengan membaca basmalah? Sebab seorang muslim mengharapkan pertolongan dan kebaikan hanya kepada Allah. Manusia tidak akan tahu hasil akhir setiap perbuatannya, sehingga basmalah adalah menyerahkan sepenuhnya atas ijin dan ridha (kehendak) Allah. Seraya berkerja dengan sungguh-sungguh, seseorang harus tetap mengharap ketentuan akhir dari Allah.

Basmalah bagian dari tawakkal. Artinya, apapun yang terjadi, itu semua terjadi atas nama Allah, karena Allah menghendaki demikian. Mengucapkan basmalah berarti melepaskan diri pada dunia materi, benda, dan berserah sepenuhnya pada kehendak Ilahi. Ada sebuah penelitian, bahwa dengan membaca basmalah, secara otomatis membuat otak kita mampu merekam setiap apa yang kita dengar (Aziz, 2008:19).

Model karakter yang ditumbuhkan melalui membaca basmalah yaitu ingin melahirkan sosok orang yang sukses dan baik. Banyak orang sukses, tetapi belum tentu baik. Membaca basmalah menguatkan diri agar secara batiniah menjadi orang yang baik, yang mendapat bimbingan dan rahmat Allah. Memulai pekerjaan dengan menyebut nama Allah, sama halnya dengan menyerahkan segala urusan kepada Allah, semua atas kehendak dan tergantung Allah. Dengan demikian, membaca basmalah berarti atas nama Allah, setiap melaksanakan tugas mulia, dapat diterima sebagai ibadah dan pengabdian kepadaNya. Seraya menggali sifat Allah yang rahman dan rahim. Yaitu kemampuan membawa rahmat dan mengorganisasikan serta membangun jaringan persatuan (ukhuwah) seluruh kekuatan umat Islam.

Sementara itu, dalam mengakhiri kegiatan perkuliahan harus ditutup dengan mengucap hamdalah. Kata hamdalah adalah pujian atas bentuk kesyukuran terhadap nikmat, karunia yang datang dari Allah. Hamdalah memuat unsur salam (keselamatan), kedamaian, dan kesejahteraan bagi hamba-hamba yang dipilih-Nya. Membaca hamdalah sebelum berakhir perkuliahan, merupakan bentuk keluasan rahmat-Nya, untuk mewujudkan kehidupan terpuji, yang selamat, damai, dan sejahtera. Tujuan ini yang hendak dicapai oleh seluruh manusia di muka bumi ini. Sehingga kata hamdalah penting diucapkan setiap kali mengakhiri pekerjaan atau perbuatan.

Dalam ajaran Islam, hamdalah merupakan segala puji bagi Allah yang 
Maha Pencipta, Pemilik, Penguasa, Pengatur, Pendidik, dan Pembimbing terhadap seluruh kehidupan di jagat raya ini. Kata Hamdalah bernilai tauhid, yang menghubungkan soal keimanan manusia kepada Allah. Oleh karenanya, iman adalah tonggak tertinggi dalam diri manusia yang tidak akan mungkin terpisah dari amal perbuatannya. Amal perbuatan yaitu cabang dari pohon iman. Makin banyak amal kebajikannya, maka makin besar dan tinggi pohonnya. Makin kuat iman seseorang, makin banyak amal saleh yang dikerjakannya. Ilustrasi tersebut seperti yang dijelaskan Allah SWT sebagai berikut:

"Tidakkah kamu perhatikan bagaimana Allah telah membuat perumpamaan kalimat yang baik seperti pohon yang baik, akarnya teguh dan cabangnya (menjulang) ke langit, Pohon itu memberikan buahnya pada setiap musim dengan seizin Tuhannya. Allah membuat perumpamaan-perumpamaan itu untuk manusia supaya mereka selalu ingat" (QS. Ibrahim : 24-25).

Islam memberikan petunjuk kepada umatnya agar tugas hidup di muka bumi ini laksana pohon yang punya akar kuat yang menghujam ke tanah, rimbun daun dan buahnya bisa menjadi makanan bagi makhluk yang ada di sekitarnya. Seorang muslim harus menjadi pohon lebat yang akarnya menancap kuat. Artinya harus punya pondasi iman yang kuat. Selain itu, juga rindang sehingga membuat siapa pun yang berinteraksi dengan dirinya merasa teduh, nyaman, dan betah tanpa curiga. Islam harus diyakini sekaligus diamalkan secara utuh, sehingga mampu membuahkan kemanfaatan, kebajikan bagi semua makhluk di sekitarnya. Kata hamdalah sejatinya merupakan konstruksi nilai yang bertumpu pada kerangka religius yang meletakkan hubungan antar manusia dalam proses aktivitas yang tidak lepas dari hubungan manusia dengan Tuhannya. Perwujudan nilai ini dapat dimaknai bahwa segala aktivitas yang dilakukan seseorang tidak bisa lepas dari keimanan dan ketakwaan kepada Allah.

Dalam hidup, keimanan dan ketakwaan inilah yang akan menjadi sumber utama spirit atau energi manusia dalam bekerja. Dengan keimanan dan ketakwaan, seseorang akan menggabungkan ilmu, keahlian, akal, dan hatinya untuk menggali dan mengelola segala potensi yang ada menjadi bermanfaat bagi kemaslahatan orang banyak (Utoyo, 2011: 24).

Bagian kedua, mengenai implementasi model karakter kepribdian (disiplin, tanggung jawab dan jujur). Dalam perkuliahan memerlukan komitmen dan kesadaran yang sangat tinggi, baik dari dosen maupun mahasiswa. Disiplin merupakan bagian penting yang diwujudkan melalui kegiatan perkuliahan. Model karakter ini dibangun melalui komitmen bersama yang tidak saja pada 
basis kepercayaan kultural, melainkan juga dokumen fungsional. Disiplin adalah sikap mental yang tercermin dalam perbuatan tingkah laku perorangan, kelompok atau masyarakat berupa kepatuhan atau ketaatan terhadap peraturan, ketentuan, etika, norma dan kaidah yang berlaku. Disiplin kerja adalah sikap kejiwaan seseorang atau kelompok yang senantiasa berkehendak untuk mengikuti atau mematuhi segala peraturan yang telah ditentukan, seperti dalam kegiatan perkuliahan.

Kedisiplinan dapat dilakukan dengan latihan antara lain dengan bekerja menghargai waktu supaya memberikan pengaruh yang positif terhadap produktivitas kerja. Dosen dan mahasiswa dapat menata waktu sedemikian rupa untuk saling mengisi dan melengkap kelemahan masing-masing. Kesepahaman dan kesadaran bersama dibutuhkan untuk menciptakan karakter disiplin dalam segala bidang. Terutama soal manajemen waktu dan hal lain yang berkaitan dengan perkuliahan. Model pembiasaan ini penting untuk membentuk kepribadian yang holistik, berbudaya dan berakhlak mulia. Sebab dewasa ini, sikap disiplin hampir hilang dari kehidupan masyarakat. Banyak orang saling serobot, mendahului, atau sebaliknya lemah, tertinggal, karena tidak terbiasa dalam mengelola waktu dan kesempatan.

Baik dosen dan mahasiswa sama-sama mentradisikan budaya disiplin, baik memulai maupun mengakhiri perkuliahan. Kedisiplinan tumbuh sebagai kesadaran bukan paksaan. Tindakan disiplin akan melahirkan energi tingkat tinggi, produktif dan mengantarkan seseorang meraih kesuksesan (Sahlan, 2010: 68). Disiplin merupakan perasaan taat dan patuh terhadap nilai-nilai yang dipercaya termasuk melakukan pekerjaan tertentu yang menjadi tanggung jawabnya. Dalam kegiatan pembelajaran di kelas, sistem telah mengatur dengan cara menanamkan nilai-nilai agar dosen dan mahasiswa memiliki kemampuan untuk menaati sebuah peraturan.

Kedisiplinan dosen dan mahasiswa adalah sikap penuh kerelaan dalam mematuhi semua aturan dan norma yang ada dalam menjalankan tugasnya sebagai pendidik dan peserta didik. Untuk meningkatkan performa akademik, sangat perlu mematuhi nilai-nilai kedisiplinan sebagai tonggak untuk menghasilkan kualitas yang baik. Hal ini seperti yang tertera dalam dokumen kontrak perkuliahan pada jurusan PAI. Dari uraian ini, maka ciri-ciri pola tingkah laku disiplin, jelaslah membutuhkan pengorbanan, baik itu perasaan, waktu, kenikmatan dan lain-lain. Disiplin bukanlah tujuan, melainkan sarana yang ikut memainkan peranan dalam pencapaian tujuan perkuliahan. Subjek (dosen dan mahasiswa) berusaha mampu mengendalikan diri dan mengatur 
cara dalam menunaikan tugasnya masing-masing. Disiplin erat hubungannya dengan produktivitas kerja dan etos kerja produktif.

Karakter tanggungjawab juga sangat penting ditanamkan dosen kepada mahasiswa. Untuk menanamkan dan mengembangkan tanggungjawab, para dosen memberikan tugas-tugas akademik, baik secara individu maupun kelompok. Para mahasiswa mengerjakan sesuai dengan instruksi yang telah dipersiapkan oleh dosen melalui RPS (Rencana Pembelajaran Semester). Mahasiswa dibentuk sedemikian rupa agar memiliki rasa tanggungjawab yang tinggi untuk mengerjakan apa yang diminta oleh setiap dosen, baik itu tugastugas terstruktur maupun tugas eksperimen (praktik).

Tanggungjawab merupakan bagian dari buah iman. Semakin kuat iman seseorang semakin besar rasa tanggungjawabnya, sebaliknya semakin tipis iman seseorang maka makin rendah rasa tanggungjawabnya. Dosen tanggungajawab dalam melaksanakan tugas mengajar, sedangkan mahasiswa tanggungjawab dalam belajarnya. Keduanya terjadi interaksi yang saling melengkapi, antara hak dan kewajibannya.

Karakter tanggungjawab muncul dalam memahami posisi masingmasing. Mahasiswa memahami posisinya dan dipenuhi sebagaimana amanah itu ditunaikan. Mahasiswa dididik dan dibimbing oleh para dosen agar tidak menyia-nyiakan kesempatan dan peluang yang begitu berharga. Sebagai amanah, maka status mahasiswa tidak boleh dipandang sepele melainkan harus dimaknai sebagai momentum yang sangat menentukan nasipnya kelak di kemudian hari.

Karakter lain yang dimunculkan dalam kegiatan perkuliahan pada jurusan PAI yaitu shiddiq (jujur). Karakter jujur mengedepankan integritas moral (akhlak), yaitu satunya kata dan perbuatan, kejujuran, sikap dan perilaku etis. Sifat jujur merupakan nilai-nilai transendental yang mencintai dan mengacu kepada kebenaran yang datangnya dari Allah SWT (Shiddiq) dalam berpikir, bersikap, dan bertindak. Perilaku "shiddiq" (shadiqun) selalu mendasarkan pada kebenaran dari keyakinannya, jujur dan tulus, adil, serta menghormati kebenaran yang diyakini pihak lain yang mungkin berbeda dengan keyakinannya, bukan merasa diri atau pihaknya paling benar. Sebaliknya, bila seseorang berbuat tidak jujur justru akan menggagu jiwanya, perilakunya serta interaksi sosialnya.

Karakter jujur ditanamkan dosen sejak mahasiswa masuk perkuliahan, terutama awal-awal semester. Mereka digiring untuk berlaku jujur dalam mengerjakan tugas-tugas yang diberikan dosen. Sekalipun berat, tetapi 
dampaknya akan manis di kemudian hari. Mahasiwa tidak bertindak asalasalan "sembrono", namun bertindak yang bertumpu pada integritas yang kuat dan mandiri.

Bagian Ketiga, mengenai implementasi model karakter sosial (toleransi, peduli sosial dan demokratis). Toleransi merupakan ajaran Islam yang sangat mulia. Secara umum toleransi adalah menghargai keragaman. Toleransi dimulai dari pikiran, tercermin dalam sikap, dan mewujud dalam perilaku. Toleransi dapat dipetakan menjadi berikut: 1) Toleransi dalam pikiran, yakni berpikir positif terhadap mereka yang berbeda antara lain karena beda agama, etnik, dan kultur. Allah menciptakan manusia berbeda-beda suku, ras dan bangsa; 2) Toleransi dalam sikap, yaitu berparasangka baik terhadap siapapun yang bukan bagian dari kita atau di luar diri kita. 3) Toleransi diwujudkan dalam perilaku, yaitu bertindak adil terhadap siapapun tanpa kebencian dan permusuhan.

Dalam kegiatan perkuliahan dosen tidak membedakan mahasiswa yang diajar berdasarkan suku, ras, golongan, status sosial, dan ekonomi. Dosen menghormati dengan memberi kesempatan belajar sesuai budaya dan kreativitas masing-masing. Karakter tentang peduli sosial juga dikembangkan dalam kegiatan perkuliahan. Karakter peduli sosial adalah sikap dan tindakan yang selalu ingin memberi bantuan pada orang lain dan masyarakat yang membutuhkan. Adapun indikator pelaksanaan karakter peduli lingkungan adalah berempati kepada sesama teman kelas, melakukan aksi sosial, dan membangun kerukunan kelas melalui FKK (forum ketua kelas).

Sedangkan model pendidikan karakter peduli sosial dalam Jurusan PAI adalah menanamkan rasa untuk sesama mahasiswa. Misalnya ada mahasiswa yang tidak masuk, karena sedang sakit, orangtua atau keluarganya terkena musibah, maka dosen dan mahasiswa bersama-sama mendoakannya. Selain itu, apabila ada yang mendapatkan kesusahan (duka cita, musibah), maka dosen selain memimpin doa juga menganjurkan ketua kelas untuk peduli terhadap teman yang mendapatkan kesusahan melalui aksi solidaritas dengan cara menghimpun dana. Kemudian dana tersebut diserahkan kepada yang bersangkutan sebagai rasa peduli dan empati.

Pendidikan karakter untuk peduli sosial adalah berkaitan dengan cara memahami ayat-ayat Al Quran tentang perintah menyantuni kaum lemah (dhuafa), dan belajar pada sifat amal shaleh. Manifestasi dari pemahaman terhadap kitab suci tersebut, kemudian muncul kesadaran ketika saat terjadi salah satu mahasiswa atau keluarganya yang mendapatkan musibah dengan 
cara mendoakan, membesuk atau ta'ziyah serta memberi bantuan moril dan materiil kepada keluarga yang bersangkutan.

Sedangkan karakter demokratis yang terjadi dalam perkuliahan pada jurusan PAI, yaitu tampak pada aktivitas pemilihan ketua kelas, gotong-royong demi kebaikan bersama, mau menerima dan memberi nasehat, serta adanya keterbukaan, apa adanya sesuai dengan kondisi dalam kelas. Sikap demokratis diterima dan dijalankan oleh semua semester. Masing-masing kelas terasa hidup dalam menjalankan roda dan fungsi organisasi kelasnya masing-masing. Organisasi kelas berjalan secara kompak, kreatif serta bahu-membahu dalam hal apa saja, termasuk sistem komunikasi sesama mahasiswa di masing-masing kelas dengan memanfaatkan FKK. Pendidikan karakter harus dimunculkan juga pada silabus, bukan hanya Nampak pada kegiatan perkuliahan, sebagaimana hasil penelitian Sadia, ternyata pendidikan karakter tidak muncul pada silabus (Sadia, 2013: 209). Pendidikan karakter harus muncul mulai silabus, buku ajar sampai kegiatan pembelajaran (Lonto, 2015: 319).

Dalam kegiatan akademik pada jurusan PAI, forum ketua kelas (FKK) dilaksanakan untuk mengontrol sistem perkuliahan. Forum tersebut diwadahi untuk mendengar secara langsung dari perwakilan kelas berbagai persoalan dan keluhan yang menyangkut perkuliahan. Ada banyak manfaat dari kegiatan forum kelas itu, seperti seberapa aktif para dosen menunaikan tugasnya, mencatat kendala-kenda teknis dalam perkuliahan, hingga usulan-usulan untuk perbaikan layanan kepada mahasiswa. Suasana demokratis dan kebersamaan terbangun untuk memberikan pembelajaran bersama. Antara mahasiswa dengan dosen bisa saling koreksi, agar terwujud suasana ideal yang optimal. Tidak ada strata lebih dominatif, apalagi otoriter dalam kegiatan perkuliahan. Antara dosen dan mahasiswa sama-sama mengerti akan tugas dan wewenangnya, antara hak dan kewajibannya, dan seterusnya. Pendidikan karakter akan membantu menciptakan generasi yang professional (Julaiha, 2014: 226).

Pendidikan karakter juga telah dilakukan pada beberapa sekolah bukan hanya di perguruan tinggi seperti di Kota Padang, pola pelaksanaan pendidikan karakter terintegrasi dianggap efektif dilaksanakan terhadap siswa di kelas (Murniyetti, 2016: 156) dan juga dilakukan pada tingkat sekolah dasar (Annur, 2016: 39) dan diintegrasikan melalui beberapa mata pelajaran (Afandi, 2011: 85). UIN sebagai lembaga pentidiikan tentunya melanjutkan dari pendidikan karakter yang sudah diperoleh ahasiswa pada saat di sekolah. Pendidikan karakter merupakan sebagai inti pendidikan nasional, yaitu membentuk manusia yang beriman, bertakwa, dan berakhlak mulia (Siswanto, 2013: 91) 
sebagaimana visi UIN Malang.

\section{Simpulan}

Berdasarkan pembahasan di atas, penulis dapat menyampaikan simpulan sebagai berikut: Pertama, model karakter religius, dikonstruk melalui pembiasaan setiap pertemuan kuliah dengan pembudayaan membaca kalimat thayyibah (basmalah dan hamdalah), melantunkan tilawah ayat-ayat al Quran, doa dan dzikir sebagai manisfestasi aktualisasi nilai-nilai keimanan dan keyakinan kepada Allah SWT baik sebelum maupun sesudah perkuliahan. Kedua, model karakter kepribadian diri, ditanamkan melalui pembiasaan disiplin, jujur dan tanggungjawab dalam semua aktivitas perkuliahan yang meliputi aspek proses pembelajaran, pelaksanaan pembelajaran, dan evaluasi pembelajaran. Desain penanamannya dituangkan melalui proses kontrak perkuliahan yang disepakati dan dipedomani oleh dosen dan mahasiswa selama perkuliahan. Ketiga, konstruksi karakter sosial, membudayakan sikap toleransi, kepedulian sosial dan demokratis. Karakter sosial ini tampak hidup dalam aktivitas perkuliahan dengan munculnya aksi-aksi nyata dalam kelas-kelas mahasiswa dengan berbagai ciri khas masing-masing.

\section{Daftar Pustaka}

Affandi, Rifqi. 2011. Integrasi Pendidikan Karakter dalam Pembelajaran IPS di Sekolah Dasar. Pedagogia. Vol. 1, No. 1: Hal. 85-98.

Annur, Fauzi. 2016. Pendidikan Karakter Berbasis Keagamaan (Studi Kasus di SDIT Nur Hidayah Surakarta). At Tarbawi. Vol. 1, No. 1: 39-56.

Aziz, M. Amin. 2008. The Power al Fatihah. Cet. III. Jakarta: Pinbuk Press.

Julaiha, Siti. 2014. Implementasi Pendidikan Karakter dalam Pembelajaran. Dinamika Ilmu. Vol. 14, No. 2: 226-239.

Kemendiknas, 2009. Pusat Kurikulum. Pengembangan dan Pendidikan Budaya dan Karakter Bangsa: Pedoman Sekolah. Jakarta: Badan Penelitian dan Pengembangan Pusat Kurikulum dan Perbukuan.

Kementerian Pendidikan Nasional (Kemendiknas). 2010. Kerangka Acuan Pendidikan Karakter Tahun Anggaran 2010. Jakarta: Direktorat Ketenagaan, Direktorat Jenderal Pendidikan Tinggi. 
Kementerian Pendidikan Nasional (Kemendiknas). 2010. Penguatan Metodologi Pembelajaran Berdasarkan Nilai-nilai Budaya untuk membentuk daya saing dan Karakter Bangsa. Jakarta: Badan Penelitian dan Pengembangan Pusat Kurikulum.

Kementerian Pendidikan Nasional (Kemendiknas). 2011. Panduan Pelaksanaan Pendidikan Karakter. Jakarta: Badan Penelitian dan Pengembangan Pusat Kurikulum dan Perbukuan.

Lonto, Apeles Lexi. 2015. Pengembangan Model Pendidikan Karakter Berbasis Nilai Sosio-Kultural pada Siswa SMA di Minahasa. Mimbar. Vol. 31, No. 2: 319-327.

Majid, Abdul dan Dian Andayani. 2012. Pendidikan Karakter Perspektif Islam. Bandung: Rosdakarya.

Mulyasa, Enco. 2012. Manajemen Pendidikan Karakter. Bandung: Rosdakarya.

Murniyetti, Engkizar dan Fuady Anwar. 2016. Pola Pelaksanaan Pendidikan Kararkter terhadap Siswa Sekolah Dasar. Jurnal Pendidikan Karakter. Vol. 6, No. 2: 156-166.

Muslich, Masnur. 2011. Pendidikan Karakter Menjawab Tantangan Krisis Multidimensional. Jakarta: Bumi Aksara.

Rahman, Amri dan Dulsukni Kasim. 2014. Pendidikan Karakter berbasis al Quran; Upaya Menciptakan Bangsa yang Berkarakter. Al-Ulum. Vol. 1, No. 1: 247-268.

Sadia, Wayan, dkk. 2013. Model Pendidikan Karakter Terintegrasi Pembelajaran Sains. Jurnal Pendidikan Indonesia. Vol. 2, No. 2: 209-220.

Sahlan, Asmaun. 2010. Mewujudkan Budaya Religius di Sekolah; Upaya Mengembangkan PAI dari Teori ke Aksi. Malang: UIN Maulana Ibrahim Malang Press.

Siswanto. 2013. Pendidikan Karakter Berbasis Nilai-Nilai Religius. Tadris. Vol. 8, No. 1: 91-107.

Syahroni. 2015. Konsep Pendidikan Karakter. Makalah, belum terpublikasikan.. 
Universitas Islam Negeri Maulana Malik Ibrahim Malang. 2016. Pedoman Pendidikan. Malang: UIN Press.

Utoyo, Indra. 2011. Manajemen Hamdalah: Melejitkan Kepemimpinan Diri dengan Teori Quranik. Bandung: Mizania. 